STUDIA SOSIA RELIGIA

Volume 2 Nomor 1, Januari-Juni 2019

E-ISSN: 2622-2019

http://jurnal.uinsu.ac.id/index.php/ssr

\title{
MITOS SUMUR LUBER DALAM PANDANGAN MASYARAKAT DESA PERKEBUNAN TELUK DALAM KECAMATAN TELUK DALAM KABUPATEN ASAHAN
}

\author{
Aprilinda M. Harahap dan Leli Ramadhani \\ Universitas Islam Negeri Sumatera Utara (UINSU) Medan \\ aprilindaharahap@gmail.com
}

\begin{abstract}
Abstrak
Mitos kini menjadi kehidupan, bahkan suatu kepercayaan yang diaktualisasikan dalam bentuk ritual tertentu yang terkadang mengandung unsur kesyirikan. Salah satu mitos yang terdapat didalam masyarakat yaitu Sumur Luber. Penelitian ini merupakan (field research) menggunakan metode kualitatif, dengan pendekatan Antropologi dan teori fungsionalisme, terhadap masyarakat Desa Perkebunan Teluk Dalam Kecamatan Teluk Dalam, Kabupaten Asahan. Berupaya menilisik pandangan masyarakat terhadap mitos Sumur Luber di Desa Perkebunan Teluk Dalam Kecamatan Teluk Dalam Kabupaten Asahan dan mengapa kini sudah tidak dipecayai lagi? Sumur Luber merupakan sumber air kesehatan, namun kini masyarakat sudah tidak lagi mempercayai karena khawatir akan kesyirikan.
\end{abstract}

Kata Kunci : Mitos, Kepercayaan, Sumur Luber

\section{Abstract}

Myth is now life, even an actualized belief in the form of certain rituals which sometimes contains elements of shirk. One of the myths contained in society is Sumur Luber. This research is a field research, using qualitative methods, with Anthropology approach and functionalism theory towards the community of Perkebunan Teluk Village, Teluk Dalam district, Asaban. Attempting to examine people's views on the myth of the Sumur Luber, at Perkebunan Teluk Village, Teluk Dalam district, Asahan and why they are no longer trusted? Sumur Luber is a source of health water, but now people no longer trust for fear of shirk.

Keyword : Myth, Beliefs, Sumur Luber

\section{Pendahuluan}

Adat dan budaya merupakan hal yang tak bisa dinafyikan dari kehidupan, yaitu berupa sebuah kepercayaan yang lahir dan berkembang pada sebuah masyarakat tertentu atau biasanya masyarakat menyebutnya dengan mitos. Kata "Mitos" berasal dari bahasa Inggris "myth" yang bermakna dongeng atau cerita yang dibuat-buat. Ahli sejarah sering mengartikan istilah mitos ini untuk merujuk kepada cerita rakyat yang tidak benar, dibedakan dari cerita buatan mereka sendiri, 
biasanya diperkenalkan dengan istilah "sejarah". Bahkan dengan mitos itu manusia dapat turut serta mengambil bagian dalam kejadian-kejadian sekitarnya dan dapat menanggapi daya kekuatan alam (Zenrif, $2008:$ 19).

Banyak mitos yang tersebar dikalangan masyarakat hingga saat ini dipercayai sebagai sebuah kebenaran secara turun-temurun. Seperti halnya, di Jawa, mitos tentang ratu penguasa laut selatan yang bernama Roro Kidul (Sujarwo, 2010 : 73), dan di Sumatera Utara terdapat mitos legenda Danau Toba serta Mitos Sumur Luber di Desa Perkebunan Teluk Dalam Kecamatan Teluk Dalam Kabupaten Asahan.

Menurut kepercayaan masyarakat Desa Perkebunan Teluk Dalam, Sumur Luber adalah sumur yang merupakan sumber air kesembuhan, sehingga sebagian besar masyarakat setempat berbondong-bondong untuk mendapatkan airnya (Thamrin, 2019).Bahkan kini air tidak sebatas penyembuh, namun dianggap sebagai sumber posistif, sehingga masyarakat menggunakannya untuk berbagai hal, seperti mencuci motor, dengan syarat setiap ingin mengambila air mereka harus memasukkan uang koin ke sumur.

Permasalahan yang timbulsaat masyarakat mengambil air sumur kini menjadi bahan pembicaraan oleh masyarakat lain atautetangga yang tidak percaya akan adanya mitos itu. Hal tersebut dilakukan masyarakat sebagai bentuk sindiran dan juga bertujuan mengingatkan bahwa yang telah dilakukan melanggar hukum Islam yang berlaku, karena dikhawtirka jatuh kepada musyrik atau menyekutukan Allah dengan air tersebut.Berdasarkan permasalahan diatas maka tulisan ini berupaya menilisik mengenai Pandangan Masyarakat mengenai Mitos Sumur Luber Desa Perkebunan Teluk Dalam yang diketahui sebagai sumber air penyembuh.

\section{Kondisi Agama dan Sosial Budaya Masyarakat}

Masyarakat Desa Perkebunan Teluk Dalam merupakan masyarakat yang heterogen karena terdiri dari berbagai macam agama yang dianut, diantaranya agama Islam, Kristen Protestan, Kristen Katolik dan lain sebagainya. Kehidupan beragamana masyarakat berjalan dengan baik dan harmonis. Berdasarkan data yang ada menunjukkan bahwa masyarakat Desa Perkebunan Teluk Dalam mayoritas agama Islam. 
Kehidupan masyarakat juga tidak terlepas dari adanya kebudayaan, dan tradisi menjadi patokan dan merupakan hal yang sangat diperhatikan dalam berbagai aspek kehidupan masyarakat yang masih menjalankan tradisi/adat jawa. Kehidupan sosial budaya masyarakat juga harmonis, sebab rasa solidaritas dan kebersamaan sangat kuat dan terjalin baik. Hal ini juga sejalan dengan anjuran Islam demi menjaga ukhuwah keberasamaan (Maratua, 2016 : 17).

\section{Pengertian Mitos}

Mitos menurut Kamus Besar Bahasa Indonesia adalah suatu cerita tentang dewa dan pahlawan zaman dahulu mengandung penafsiran tentang asal-usul alam semesta, manusia dan bangsa itu sendiri yang memiliki arti mendalam yang diutarakan dengan cara gaib (Tim, 1999 : 600).Kamus Ilmiah Populer, mitos adalah berhubungan dengan kepercayaan primitif tentang kehidupan alam gaib, yang timbul dari usaha manusia itu sendiri yang tidak ilmiah dan tidak berdasarkan pada pengalaman yang nyata untuk menjelaskan sesuatu (Pius, 2001 : 475).

Dalam pandangan masyarakat primitif, mitos dianggap sebagai suatu cerita yang benar dan cerita ini menjadi milik mereka yang paling berharga, bahkan merupakan suatu gambaran tentang keyakinan, karena mitos merupakan sesuatu yang suci, bermakna, dan menjadi contoh model tindakan manusia serta memberikan makna dan nilai pada kehidupan ini. Mitos menceritakan bagaimana suatu realitas mulai bereksistensi melalui tindakan makhluk supranatural. Mitos selalu menyangkut suatu penciptaan. Adeng (2011 : 166 ) bahwa fungsi utama dan esensial dari mitos jika ditarik satu benang merah adalah untuk menjustifikasi tindakan-tindakan magic, sebagai sebuah pedoman praktis dalam menyikapi dan melakukan hubungan dengan yang supranatural.

Sedangkan pengertian mitos menurut masyarakat Desa Perkebunan Teluk Dalam adalah suatu cerita yang terbentuk secara lisan yang dibuat oleh manusia itu sendiri dan dibesar-besarkan oleh manusia itu sendiri pula serta dipercayai secara turun-temurun. Mitos dalam masyarakat Desa Perkebunan Teluk Dalam lebih cepat berkembang di dalam masyarakat suku Jawa, karenamasyarakat suku Jawa di Desa Perkebunan Teluk Dalam masih percaya terhadap hal-hal ghaib. Dan juga dari sejak kecil mereka sudah ditanamkan untuk percaya takhayul. Mereka diajarkan untuk percaya, bukan untuk mempertanyakan, karena memang anak-anak belum memiliki kemampuan untuk berfikir secara kritis. 
Psikologis anak-anak yang dibentuk untuk "mempercayai" terus terbawa sampai dewasa, sehingga ketika sejak kecil mereka sudah bisa menerima tahayul, maka adalah hal yang sangat mudah untuk menerima tahayul, mitos dan lainnya ketika dewasa (Andri , 2019). Sunardi (2019) menyatakan mitos sebenarnya adalah serangkaian cerita, yang bisa saja memang memiliki dasar asal-usul dan bisa saja tidak, yang kemudian muncul dan bertahan sekian waktu karena terusmenerus diperbincangkan dan diingat dalam masyarakat tertentu. Semakin kuat dan sering mitos tersebut diangkat, dibicarakan, maka akan semakin bertahan mitos tersebut dikalangan masyarakat.

\section{Sejarah Mitos Sumur Luber Di Desa Perkebunan Teluk Dalam}

Sumur Luber merupakan sebuah sumur zaman peninggalan Belanda yang terletak di tengah-tengah perkebunan kelapa sawit PT. Padasa Enam Utama Desa Perkebunan Teluk Dalam Kecamatan Teluk Dalam Kabupaten Asahan. Disekitar sumur luber dahulunya ada rumah para karyawan, sehingga sumur tersebut dimanfaatkan oleh para karyawan untuk melakukan aktifitas sehari-hari seperti mandi dan mencuci pakaian. Saat sekarang rumah para karyawan perkebunan sudah tidak ada lagi sehingga sumur tersebut hanya dimanfaatkan untuk meracun rumput yang berada dilahan perkebunan.

Sumur luber berasal dari bahasa Jawa “Luber”yang berarti meluap. Sumur luber memiliki mata air yang cukup deras sehingga meluap dan keluar dari dasar sumur, padahal sebelumnya air sumur luber itu kering (Fauzi : 2019).Sejak tahun 1998 sumur luber dianggap sumur bernuansa mistis yang memiliki air berkhasiat bisa menyembuhkan berbagai macam penyakit. Awal dasar masyarakat percaya kepada air sumur tersebut dikarenakan ada salah seorang warga Desa Perkebunan Teluk Dalam mengidap penyakit kulit, kemudian warga tersebut memandikan air dari sumur luber dan mendapat kesembuhan. Setelah itu warga yang mendapat kesembuhan memberitakan kepada warga-warga desa tentang kemujaraban air sumur luber. Sehingga warga setempat maupun luar desa datang untuk melihat sumur luber dan mengambil airnya (Fauzi : 2019).

Ada juga masyarakat yang tidak mempercayai kemujaraban air sumur luber. Masyarakat yang tidak mempercayai khasiat sumur luber tersebut mendatangi langsung lokasi sumur luber untuk membuktikan kebenaran pendapatnya, bahwa air sumur luber itu tidak berkhasiat. Namun, 
pada saat warga tersebut berada di sekitar sumur tiba-tiba warga tersebut masuk ke dalam sumur dan meninggal dunia dalam sumur luber (Makmurun : 2019)

Kemujaraban dari air sumur luber berlangsung selama 6 tahun, dari tahun 1998 sampai 2004. Ditahun 2004 hingga sekarang masyarakat tidak lagi mempercayai khasiat dari air sumur luber dikarenakan adanya beberapa sebab. Diantaranya: terdapat beberapa oknum yang menjual air dari sumur luber dikarenakan keserakahan mereka. Air tersebut dijual dengan harga Rp 15.000 untuk dua liter air. Selain airnya yang dijual, lokasi sumur luber dijadikan tempat sebagian orang bermain judi, mabuk-mabukan dan adanya kupu-kupu malam. Karena sering airnya diambil sumur luber mengalami kekeringan sehingga warga tidak lagi mengambil air sumur luber (Makmurun : 2019).

Pada tahun 2005 ada salah seorang warga Kisaran bernama Suryanto mendatangi sumur luber bersama salah seorang warga Perkebunan Teluk Dalam yang bernama Fauzi. Ketika mereka berada di lokasi sumur luber, Fauzi menunjukkan sumur luber itu kepada Suryanto dengan jarinya. Seketika pada saat Fauzi menunjuk kearah sumur luber tiba-tiba air tersebut menyembur keluar sampai dua kali semburan, padahal sebelumnya air sumur luber mengalami kekeringan (Fauzi : 2019).

Ketika isu tentang kemujaraban air sumur luber tidak terdengar lagi, tiba-tiba ada seorang warga yang mendapatkan mimpi bahwa kelak air yan berada di dalam sumur luber suatu saat akan memberikan khasiat sebagaimana pada masa dahulu. Dan pada saat sekarang sumur luber dijadikan cagar alam yang perlu dilidungi dan dibuat pembatas oleh Adm. Perkebunan Teluk Dalam bernama Lambok (Fauzi : 2019).

\section{Paradigma Masyarakat Terhadap Mitos Sumur Luber}

Para sosiolog memandang bahwasanya kehidupan manusia sepanjang sejarahnya selalu dibayangi oleh suatu hal yang biasa dinamakan dengan agama. Agama sebagai system sosial budaya merupakan objek yang menjadi perhatian utama dalam antropologi agama. Sebab, kehidupan beragama memiliki pengaruh terhadap aspek kebudayaan yang lainnya (Bustamin, 2005 :201). 
Agama diyakini sebagai wahyu Tuhan yang menjadi pedoman manusia menjalani kehidupannya, dan suatu kebenaran yang tidak dapat dipungkiri. Sedangkan tindakan manusia meyakini agama dalam bentuk apa pun merupakan realitas sejarah yang tidak dapat diragukan lagi. Oleh sebab itu, dari masa ke masa, manusia manapun tidak akan dapat melepaskan diri dari agama. Orang melihat agama yang ada di dunia ini secara menyeluruh akan mendapatkan paham dalam bentuk yang sangat rumit. Sejak dulu hingga sekarang, bentuk-bentuk implementasi keyakinan beragama terus berkembang. Keyakinan tersebut telah menghasilkan ritual-ritual dan praktik-praktik yang tidak terhingga jumlahnya. Ritual-ritul itu merupakan bentuk usaha manusia untuk memberikan suatu makna bagi alam dan kehidupan disekitarnya (Arifinsyah 2018 : 22).

Sejatinya, agama dalam kehidupan manusia berkaitan dengan pencarian makna hidup, atau bagaimana seharusnya manusia memaknai hidup. Pencarian makna hidup ini, setidaknya didorong kesadaran eksistensial manusia. Dari mana, untuk apa, dan mau kemana perjalanan di dunia ini. jawabannya adalah dari Yang Maha Suci untuk hidup sebagai manusia yang penuh kesucian, dan menuju ke puncak Yang Maha Suci. Intinya manusia adalah makhluk pencari makna hidup yang didasari oleh niat yang suci, pejuang dan mengabdi untuk mencapai kedamaian abadi (Arifinsyah, $2016: 15)$.

Harsojo menyebutkan sistem kepercayaan agama sebagai bagian dari aspek kebudayaan bersinergi dengan kebudayaan yang lainnya pada aspek-aspek: teknologi dan kebudayaan materil, sistem ekonomi dan mata pencaharian, organisasi sosial, sistem kepercayaan, dan kesenian. Senada dengan pandangan ini, Koentjoroningrat juga menyebutkan Agama sebagai "Cultural Universal” dengan unsur-unsur: bahasa, sistem pengetahuan, organisasi sosial, sistemperalatan hidup dan teknologi, sistem mata pencaharian, sistem religi, dan kesenian (Koentoneingrat, 1989 : 132).

Masyarakat Desa Perkebunan Teluk Dalam terdiri dari berbagai macam suku diantaranya, suku jawa, suku batak, suku melayu dan yang lainnya. Namun, mayoritas suku yang ada di Desa Perkebunan Teluk Dalam ialah suku Jawa. Dalam masyarakat suku jawa, mereka memiliki kebudayaan-kebudayaan Jawa. Menurut Magis kebudayaan Jawa mempunyai ciri khas, yaitu terletak dalam kemampuan yang luar biasa untuk membiarkan diri dibanjiri oleh gelombanggelombang kebudayaan yang datang dari luar dan dari dalam. Karena kebudayaan Jawa yang 
mempunyai ciri khas mudah untuk menerima kebudayaan luar dan masih mempertahankan keasliannya. Kebudayaan suku Jawa di Desa Perkebunan Teluk Dalam menerima dengan baik kebudayaan Islam yang dibawa oleh para wali.

Dampak yang ditimbulkan dari dakwah yang dilakukan para Wali tersebut salah satunya yaitu terjadilah asimilasi kebudayaan Islam dan Jawa pada masyarakat Desa Perkebunan Teluk Dalam. Namun, seiring berjalannya waktu meskipun agama Islam sudah diterima oleh masyarakat Desa Perkebunan Teluk Dalam namun keyakinan-keyakinan terhadap hal-hal gaib yang sudah menjadi kebiasaan dan kepercayaan masyarakat sebelumnya sulit untuk dihilangkan dari identitas masyarakat Desa ini. Salah satu mitos yang cukup familiar pada zaman dahulu sampai saat ini yaitu masyarakat Desa Perkebunan Teluk Dalam masih mempercayai mitos sumur luber yang merupakan sebuah sumur peninggalan zaman Belanda.

Pandangan dari masyarakat mengenai mitos sumur luber di Desa Perkebunan Teluk Dalam ini cukup bervariasi. Dimana, sebagian masyarakat berpandangan bahwa yang menganggap bahwa air sumur luber memang benar-benar berkhasiat dan bukan sekedar mitos. Sebab masyarakat tersebut telah membuktikan khasiat dari sumur luber itu. Selanjutnya sebagian masyarakat menganggap bahwa air sumur luber yang airnya berkhasiat hanyalah sebuah mitos. Dan pandangan masyarakat yang terakhir menganggap bahwa orang yang mempercayai khasiat dari air sumur luber tergolong kepada perbuatan syirik.

Masyarakat yang menganggap bahwa air sumur luber berkhasiat dan bukan sekedar mitos adalah masyarakat yang memiliki penyakit kulit dan ketika masyarakat tersebut datang ke sumur luber lalu mandi di sumur tersebut seketika gatal-gatal yang diderita masyarakat tersebut hilang dan mengalami kesembuhan. Pandangan masyarakat yang menganggap bahwa air sumur luber hanya sebuah mitos adalah masyarakat yang ketika mengambil air dari sumur luber dan menggunakan air sumur luber untuk menghilangkan penyakit yang diderita, namun tidak ada khasiat yang ditimbulkan dari air tersebut.

Dalam pandangan Bapak Sugiharto bahwa air sumur luber memiliki nuansa mistis sehingga percaya atau tidak air sumur luber memang bisa memberikan kesembuhan kepada orang yang menggunakannya (Sugiharto : 2019). Pandangan masyarakat yang menganggap bahwa percaya terhadap khasiat dari air sumur luber adalah perbuatan syirik. Sehingga masyarakat 
tersebut tidak pernah datang dan mengambil air sumur luber. Menurut bapak Rahman Nainggolan air sumur luber tidak ada bedanya dengan air sumur lainnya. Air sumur luber hanyalah air yang biasa pada umumnya dan tidak memiliki khasiat apapun. Sebab percaya kepada sesuatu yang belum pasti akan menjatuhkan pelakunya kepada perbuatan syirik (Rahman : 2019). Menurut beliau, air yang lebih baik dan bisa menyembuhkan ialah air zam-zam. Berdasarkan hadist Rasulullah:

\section{خير ماء علي وجه الارض ماء زمزم فيه طعام من الطعم وشفاء من السقم}

Artinya: "Air terbaik diselurub permukaan bumi adalah air zam-zam, di dalamnya terdapat makanan (yang membangkitkan) selera, obat dari berbagai penyakit". (HR. Ath-Thabrani Dalam Al-Mu'jam Al-Kabir).

\section{Pengaruh Mitos Sumur Luber Terhadap Masyarakat Setempat}

Adat merupakan salah satu hal yang melekat pada kehidupan masyarakat. Dengan berkeyakinan pada adat yang ada masyarakat tidak perlu ragu dalam menjalani setiap aktivitas kemasyarakatan karena di dalam setiap adat sudah terdapat beberapa hukum untuk mengatur kehidupan bermasyarakat. Berdasarkan ensiklopedi telah dijelaskan bahwa adat adalah suatu kebiasaan atau tradisi masyarakat yang telah dilakukan secara turun-temurun. Kata adat ini lazim digunakan tanpa membedakan mana yang mempunyai sanksi seperti hukum adat dan yang mana tidak mempunyai sanksi disebut adat saja (Ensiklopedi, 1999 : 21).Mitos merupakan bagian atau unsur dari adat. Dengan adanya adat maka sebuah mitos dapat lahir dan dipercaya secara turuntemurun. Masyarakat Jawa tidak pernah terlepas dari adat-istiadat dan juga mitos. Salah satu mitos yang terdapat di dalam masyarakat adalah mitos sumur luber.

Sumur luber yang merupakan sumur zaman peninggalan Belanda terletak di tengahtengah perkebunan sawit milik PT. Padasa Enam Utama. Keberadaan sumur luber oleh warga setempat dijadikan tempat untuk mandi. Pada saat sekarang air dalam sumur luber tidak lagi berkhasiat, sehingga masyarakat menggunakan air tersebut untuk mencuci tangan dan kaki ketika selesai meracun rumput dilahan perkebunan PT. Padasa Enam Utama.

Adapun pengaruh keberadaan sumur luber memberikan dampak yang positif bagi masyarakat, namun disamping itu tidak terlepas dari dampak negatifnya. Pada era 1998 sampai 2004 air dari sumur luber dipercaya bisa menyembuhkan berbagai macam penyakit seperti 
penyakit kulit, penyakit lumpuh, penyakit mata dan yang lainnya. Berita tentang kemujaraban air pun terdengar sampai ke daerah Mandailing Natal, Aceh dan Nusa Tenggara Timur. Sehingga satu bus pariwisata pernah mendatangi lokasi sumur luber untuk melihat dan mengambil air yang mujarab tadi. 1 kali 24 jam sumur luber ramai dipadati oleh masyarakat. Baik itu masyarakat setempat, masyarakat diluar desa perkebunan dan sampai masyarakat diluar kabupaten Asahan.

Keberadaan sumur luber juga memberikan pengaruh terhadap perekonomian sebagian masyarakat Desa Perkebunan Teluk Dalam, sebab para pengunjung yang mendatangi lokasi sumur luber itu banyak yang menggunakan kendaraan pribadi. Dan hal ini pun dimanfaatkan oleh sebagian masyarakat untuk membuat lokasi parkir, adapun tarif dari pengunjung yang memparkirkan kendaraannya itu ialah Rp 1.000. Bapak Sukirman selaku penjaga parkir di lokasi sumur luber mengatakan bahwa meskipun ia terlibat dalam mengambilkan air untuk para pengunjung, namun ia sendiri tidak percaya akan khasiat dari air sumur luber tersebut (Sukirman : 2019).Masyarakat yang mengambil air dari sumur luber harus membayar kepada para penimba yang berada dilokasi sumur tersebut, sehingga menguntungkan perekonomian bagi para penimba itu.

Selain pengaruh-pengaruh diatas, ada juga dampak negatif yang ditimbulkan dengan adanya mitos sumur luber tersebut, diantarnya: karena banyaknya orang yang mengambil air sumur luber, seingga dimanfaatkan untuk membuat tempat perjudian dibawah pohon sawit PT. Padasa Enam Utama. Serta adanya kupu-kupu malam yang memanfaatkan keramaian pada lokasi sumur luber.

Fath al-dzari'ah adalah "suatu perbuatan yang dapat membawa kepada sesuatu yang dianjurkan, bahkan diwajibkan syara', sesuai dengan kaidah yang menjadi dasar penggunaan fath aldrariaab” mengatakan:

\section{ما لا يتم الو اجب الا بـ فهوواجب}

"Tika suatu kewajiban tidak sempurna dilaksanakan tanpa suatu hal tertentu, maka bal tertentu itu pun wajib pula untuk dilaksanakan" (Nasrun, 1997).

Begitu juga apabila segala jalan menuju pada sesuatu yang haram, maka sesuatu itu pun haram, sesuai kaidah: 


\section{مادل علي حر ام فهو حرام \\ "Segala jalan yang menuju terciptanya suatu pekerjaan yang haram, maka jalan itu pun dibaramkan".}

Berdasarkan sudut pandang Islam dapat diketahui bahwa efek buruk yang ditimbulkan ketika mempercayai mitos sumur luber merupakan washilah untuk menyembuhkan penyakit maka tergolong kepada suatu yang haram.

\section{Analisis Mitos Sumur Luber Dalam Konteks Kewahyuan}

Mempercayai adanya kekuatan lain selain Allah termasuk ke dalam perbuatan syirik. Sama seperti dengan mempercayai air dari sumur luber yang berkhasiat untuk menyembuhkan berbagai macam penyakit. Sebagai seorang muslim sewajarnya meyakini bahwa Allah lah sang pencipta sekaligus pemberi rezeki, pemberi kesembuhan dan tidak ada pertolongan selain pertolongan Allah. Sebagaimana dalam Al-Qur'an surah At-thalaq ayat 3:

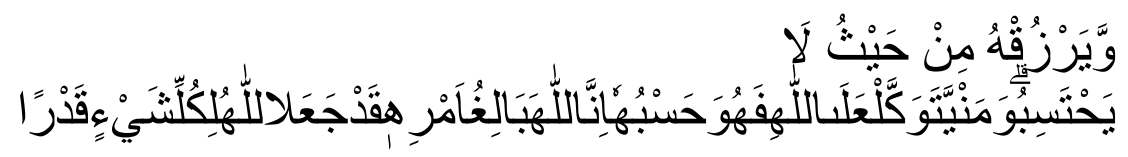

Artinya: "Dan Dia memberinya rezeki dari arah yang tidak disangka-sangkanya. Danbarangsiapa bertawakal kepada Allah, niscaya Allab akan mencukupkan (keperluan)nya. Sesunggubnya Allah melaksanakan urusan-Nya. Sungguh, Allab telah mengadakan ketentuan bagi setiap sesuatu”.

Perbuatan syirik merupakan salah satu dari dosa besar, yang pelakunya akan kekal di dalam neraka: Firman Allah dalam Alqur'an Surah An-Nisa ayat 48:

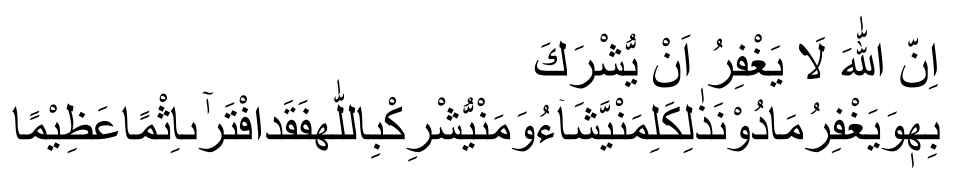

Artinya: "Sesungguhnya Allah tidak akan mengampuni dosa syirik, dan Dia mengampuni segala dosa yang selain dari syirik itu, bagi siapa yang di-kehendaki-Nya. Barang siapa yang mempersekutukan Allah, maka sunggub ia telah berbuat dosa yang besar".

An-Nisa ayat 116:

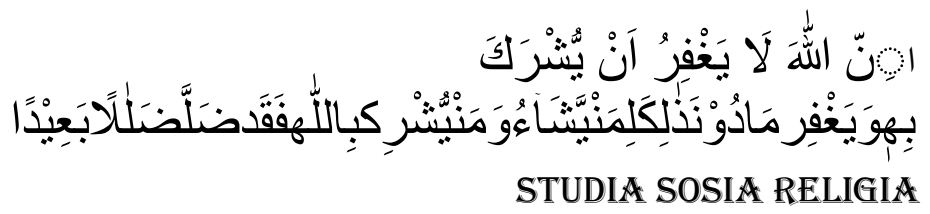

Volume 2 Nomor 1, Januari-Juni 2019| 48 
Artinya: "Sesunggubnya Allah tidak mengampuni dosa mempersekutukan (sekutu) dengan Dia, dan Dia mengampuni dosa selain dari syirik itu bagi siapa yang dikehendaki-Nya. Barang siapa yang mempersekutukan (sesuatu) dengan Allah, maka sesunggubnya ia telah tersesat sejauh-jaubnya."(Depag, $1971: 126)$

Dalam Hadits Nabi Muhammad Saw dari Annas Bin Malik r.a berkata Rasulullah saw. bersabda :

Artinya: "Telah dikemukakan kepada Rasulullab saw. (ditanyaiNya) tentang dosa-dosa besar, lalu Rasulullah saw. bersabda: syirik kepada Allah, membunuh jiwa, dan durhaka kepada ibu-bapak”.'(Al-Bukhori).

Ibnu Katsir mengatakan, bahwa "syirik"digolongkan dosa besar, karena perbuatan syirik menyetarakan kedudukan Tuhan sementara hanya Dialah yang memberi semua nikmat dan berhala-berhala yang tidak memiliki nikmat. Ayat dan Hadist di atas menjelaskan secara tegas bahwa mitos termasuk salah satu bentuk kesyirikan, dan syirik merupakan salah satu dosa terbesar setelah membunuh dan durhaka kepada orang tua.

Berdasarkan “absab nuұu”ayat tersebut bahwa syirik yang dimaksud adalah “kemusyrikan”dimana di samping mensyarikatkan Allah, juga melakukan sifat-sifat kemunafikan (seperti percaya kepada mitos sumur luber) dan Al-Maraghy mengatakan, bahwa Nabi saw. menafsirkan ayat tersebut, adalah perbuatan yang mengadakan tuhan-tuhan selain Allah dengan jalan merumuskan hukum-hukum halal dan haram tersendiri untuk ditaati.

Dalam Alquran dan Hadis di atas menjelaskan secara jelas dan tegas bahwa betapa perbuatan "syirik" itu akan menimbulkan dampak yang amat berbahaya bagi kehidupan keagamaan berupa antara lain; pertama tidak mendapatnya pengampunan dari Allah, sebagaimana permulaan ayat mengatakan bahwa tidak diampuni-nya dosa "syirik", karena dapat merusak diri. Kedua, tergolong dosa yang amat besar sebagaimana penutup bahkan sebesar-besarnya dosa besar. Ketiga, sesesat-sesat kesesatan, sebagaimana penutup ayat 116, Al-Maraghy mengatakan bahwasanya orang-orang yang melakukan perbuatan "syirik" itu telah tersesat dari tujuan atau sudah sangat jauh dari jalan yang lurus, sebab “syirik"merupakan kesesatan yang merusak akal, menodai kejernihan ruh, dan menjadikannya tunduk kepada hamba lain selain dirinya sendiri. Keempat penyembahan terhadap syaitan (percaya kepada mitos dan mistis) sebagaimana AlMaraghy mengatakan, diantara pekerjaan dan tuntutan tabiat syaitan ialah menyesatkan dan 
menyibukkan para hamba dengan angan-angan kosong yang bathil (jauh dari hak dan hidayah). Demikian ayat diatas menjelaskan tentang berbahayanya dan perlunya menjauhi perbuatan syirik itu sehingga Allah mengulanginya dalam surah yang sama dan dengan antar ayat yang agak berdekatan dan bunyi yang hampir sama.

\section{Analisis Mitos Sumur Luber Dalam Konteks Studi Agama-Agama}

Masyarakat merupakan suatu kesatuan hidup manusia yang terikat dengan suatu sistem adat istiadat. Dalam antropologi budaya, suku Jawa merupakan sutau masyarakat yang mana di dalam kehidupan sehari-hari mereka menggunakan bahasa Jawa sebagai alat komunikasidan terikat oleh norma-norma hidup karena sejarah, tradisi, maupun agama.

Sama seperti halnya masyarakat Desa Perkebunan Teluk Dalam. Masyarakat di Desa Perkebunan Teluk Dalam sangat menghormati antara satu dengan yang lain, khususnya hal yang menyinggung budaya dan tradisi dalam suatu masyarakat. Kelompok masyarakat yang kurang memiliki wawasan yang cukup terhadap keyakinan yang dianut, lebih memilih melestarikan warisan para leluhurnya dan mempraktekkan di dalam kehidupan sehari-hari, walaupun sangat bertolak belakang dengan keyakinan yang mereka percayai. Sebagian masyarakat yang belum memahami agama Islam menganut paham animisme dan dinamisme sebagai sistem keyakinan mereka dalam kehidupan sehari-harinya.

Animisme berasal dari kata "anima" yang bermakna "nyawa". Jadi, Animisme merupakan ajaran atau doktrin tentang realitas jiwa. Dalam studi tentang sejarah agama primitif, ada beberapa istilah yang memiliki pengertian hampir sama, yaitu:

a. Necrolatry merupakan penyembahan kepada roh-roh atau jiwa manusia dan binatang, terutama penyembahan kepada roh-roh manusia yang telah tiada.

b. Spritisme merupakan penyembahan terhadap makhluk spritual yang tidak dihubungkan dalam suatu cara yang mapan dengan jasad-jasad dan objek-objek tertentu.

c. Naturisme yaitu penyembahan terhadap makhluk spritual yang dikaitkan dengan fenomena alam dan kekuatan kosmis yang besar seperti angin, sungai-sungai, binatangbinatang dan juga objek-objek yang menyelimuti bumi, yaitu tanam-tanaman dan binatang.

d. Animisme yang titik berat penyembahannya yaitukepada makhluk-makhluk spritual yang tidak dapat dijangkau oleh panca indera manusia. 
Jadi, pengertian nyawa dalam paham animisme adalah "daya kekuatan yang hidup" yang dapat tinggal dalam manusia, binatang, tumbuh-tumbuhan atau dalam segala yang ada.

Sedangkan pengertian Dinamisme berasal dari kata "dunamos" yang berarti kekuatan, kekuasaan dan daya. Singkatnya, dinamisme adalah kepercayaan terhadap benda-benda di sekitar manusia yang diyakini memiliki kekuatan ghaib. Maksud dari kekuatan ghaib tersebut adalah kekuatan yang berada dalam suatu benda (bisa berasal dari api, air, batu-batuan, benda ciptaan, pepohonan, dan hewan) yang dapat memberikan manfaat (Rahmat, $2012: 29$ ).

Menurut hemat penulis masyarakat Desa Perkebunan Teluk Dalam yang percaya terhadap mitos sumur luber memiliki paham dinamisme, hal tersebut karena mereka mempercayai adanya kekuatan ghaib yang terdapat dalam air sumur luber. walaupun agama yang dianut masyarakat Desa Perkebunan Teluk Dalam ialah mayoritas agama Islam. Tetapi dalam aspek sosio-kultural yang telah banyak menjadikan rentetan peristiwa dan keyakinan sehingga masuk dalam kategori konstruksi keyakinan yang khas, tanpa menegasikan aspek-aspek kondisisi realitas dari kebertuhanan masyarakat itu sendiri, hal tersebut dimaksudkan bahwa pengaruh yang kuat dan saling bergantung satu dengan yang lainnya terkait dengan dimensi keagamaan dan dimensi kondisi realitas masyarakat itu yang percaya pada mitos tersebut.

Keharmonisan antara dua dimensi diataslah yang menurut hemat penulis mampu memberikan pengaruh besar dengan kondisi keberagaman dari ritual-ritual keagamaan dan ritual diluar kegamaan yang dalam padanannya tanpa menafikan dan menegasikanbahwa hal tersebut merupakan sebuah kreasi kebudayaan yang khas dan unik yang berada ditengah-tengah masyarakat yang penulis teliti.

\section{Penutup}

Dalam pandangan masyarakat Desa Perkebunan Teluk Dalam terdapat tiga macam hasil pandangan yang telah diteliti: pertama, masyarakat yang percaya akan kebenaran mitos dari air sumur luber memang benar berkhasiat bisa menyembuhkan berbagai macam penyakit;kedua, masyarakat yang menganggap air sumur luber hanyalah mitos; ketiga, masyarakat yang menganggap orang yang percaya bahwa mitos sumur luber bisa menyembuhkan berbagai macam penyakit akan tergolong ke dalam perbuatan syirik. 
Saat ini masyarakat tidak mempercayai akan mitos sumur luber, disebabkan adanya masyarakat yang menjual air dari sumur lumur tersebut. Selain airnya yang dijual terkadang masyarakat berbuat curang yaitu dengan menjual air dari sumur lain dan mengatakan air itu berasal dari sumur luber. Disamping itu sebagian lokasi dari air sumur luber dijadikan tempat masyarakat bermain judi dan minum-minuman keras dan psk yang menjual diri karena di lokasi sumur luber satu kali dua puluh empat jam ramai didatangi oleh masyarakat yang ingin mengambil air dari sumur luber.

\section{Daftar Pustaka}

Agus, Bustanuddin, Agama Dalam Kehidupan Masyarakat: Pengantar Antropologi Agama, Jakarta: Rajawali Pers, 2005.

Agus, Bustanuddin. Agama Dalam Kehidupan manusia : Pengantar Antropologi Agama, Jakarta: PT. Raja Grafindo Persada, 2006.

Arifinsyah, Agama Dialogis, Medan: Perdana Publishing, 2016.

Arifinsyah, Ilmu Perbandingan Agama Dari Regulasi ke Toleransi, Medan: Perdana Publishing, 2018.

Arikunto, Suharsimi , Managemen Pendidikan, Jakarta: Rineka Cipta, 2000.

Badan Pusat Statistik.

Depag RI, Al-Qur'an dan Terjemahan, Jakarta: Yayasan Penyelenggara Penterjemah/Pentafsiran AlQur'an, 1971

Ensiklopedia Islam, Jilid I Cet Ke-3, Jakarta: PT. Ichtiar Baru van Hoero, 1999.

Harikunto, Suharsimi, Prosedur Penelitian Suatu Pendekatan Praktek, Jakarta : PT Rineka Cipta.

Hidayatullah, Agus et al. Alwasim: Al-Qur'an Tajwid dan Terjemah. Bekasi: Cipta Bagus Segara, 2013.

Koentjoroningrat, Kebudayaan, Moralitas, dan pembangunan, Jakarta: Gramedia, 1989.

Koentjoroningrat. Pengantar Ilmu Antropologi. Jakarta: Rineka Cipta, 2009.

Margono, S, Metode Penelitian Dan Pendidikan, Jakarta: Rineka Cipta, 2004.

Nasrun Haroen, Ushul Fiqih I, Ciputat: PT. Logos Wacana Ilmu, 1997.

Ningrat, Koentjoro, Metode-Metode Penelitian Masyarakat Jakarta: Gramedia Pustaka, 1997.

Noor, Juliansyah. Metodologi Penelitian: Skripsi, Tesis, Disertasi, dan Karya Ilmiah. Jakarta: Kencana Prenada Media Group, 2012. 
Mitos Sumur Luber dalam Pandangan Masyarakat Desa Perkebunan Teluk Dalam Kecamatan Teluk Dalam Kabupaten Asahan

O’Dea, Thomas f. The Sociology Of Religion. Englewood Cliffs, New Jersyey. 1966. Diterjemhkan oleh Tim Penerjemah Yasogama. Rajawali: Jakarta, 1985.

Partanto, Pius A dan M. Dahlan Al Barry, Kamus Ilmiah Populer, Surabaya: Arkola, Muchtar Ghazali, Adeng, Antropologi Agama, Bandung: Alfabeta, 2011.

Partanto, Pius. A dan Al Barry, M. Dahlan,Kamus Ilmiah Populer, Surabaya : Arkola, 2001.

Fajri Rahmat dkk, Agama-Agama Dunia, Yogyakarta: Jurusan Perbandingan Agama Fakultas Ushuluddin, Studi Agama dan Pemikiran Islam, 2012.

Sudjana, Nana, Awal Kusuma, Proposal Penelitian Di Perguruan Tinggi, Bandung: Sinar Baru Algnesindo, 2008.

Sugiyono, Metode Penelitian Pendidikan: Pendekatan Kualitatif, Kuantitatif dan R\&D. Bandung: Alfabeta, 2010.

Sujarwo,Ilmu Sosial dan Budaya Dasar. Yogyakarta: Pustaka Pelajar, 2010.

Syafaruddin, et al, Metodologi Penelitian, Medan: Fakultas Tarbiyah Institut Agama Islam Negeri Sumatera Utara, 2006.

Tim Penyusun Kamus Pusat Pembinaan dan Pengembangan Bahasa, Kamus Besar Bahasa Indonesia, Jakarta: Balai Pustaka, 1999.

Zenrif, M. F, Realitas Keluarga Muslim Antara Mitos dan Doktrin Agama. Malang: UIN Malang Press, 2008.

Wawancara dengan Andrianto, (Sekretaris Desa Perkebunan Teluk Dalam)

Wawancara dengan Fauzi, (Tokoh Agama Desa Perkebunan Teluk Dalam)

Wawancara dengan Makmurun, (Kepala Dusun Desa Perkebunan Teluk Dalam)

Wawancara dengan Rahman Nainggolan, (Tokoh Agama Desa Perkebunan Teluk Dalam)

Wawancara dengan Sugiharto(Kepala Desa Perkebunan Teluk Dalam)

Wawancara dengan Sukirman, (Penjaga Parkir Di Sumur Luber)

Wawancara dengan Sunardi, (Masyarakat Desa Perkebunan Teluk Dalam)

Wawancara dengan Thamrin (Masyarakat Desa Perkebunan Teluk Dalam)

Website: https://kbbi.kemdikbud.go.id/pandangan 